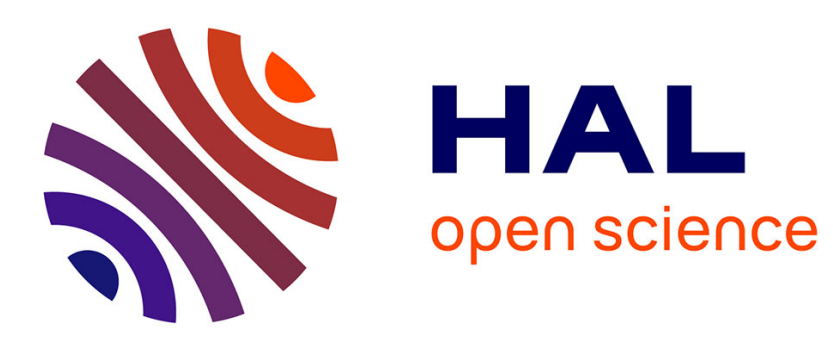

\title{
Influence of iron on the alteration of the SON68 nuclear glass in the Callovo-Oxfordian Groundwater
}

\author{
T. de Echave, M. Tribet, S. Gin, C. Jegou
}

\section{To cite this version:}

T. de Echave, M. Tribet, S. Gin, C. Jegou. Influence of iron on the alteration of the SON68 nuclear glass in the Callovo-Oxfordian Groundwater. Applied Geochemistry, 2019, 100, pp.268-278. 10.1016/j.apgeochem.2018.12.007 . cea-02339848

\section{HAL Id: cea-02339848 https://hal-cea.archives-ouvertes.fr/cea-02339848}

Submitted on 16 Mar 2020

HAL is a multi-disciplinary open access archive for the deposit and dissemination of scientific research documents, whether they are published or not. The documents may come from teaching and research institutions in France or abroad, or from public or private research centers.
L'archive ouverte pluridisciplinaire HAL, est destinée au dépôt et à la diffusion de documents scientifiques de niveau recherche, publiés ou non, émanant des établissements d'enseignement et de recherche français ou étrangers, des laboratoires publics ou privés. 


\title{
Influence of iron on the alteration of the SON68 nuclear glass in the Callovo- Oxfordian Groundwater
}

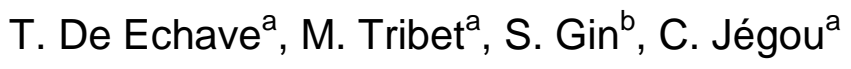 \\ ${ }^{a}$ CEA,DEN,DE2D,SEVT,LMPA, BP 17171, F-30207 Bagnols-sur-Cèze Cedex, \\ France
}

${ }^{b}$ CEA,DEN,DE2D,SEVT,DIR, BP 17171, F-30207 Bagnols-sur-Cèze Cedex, France

* Corresponding author. Tel.: +33466339152.

Email address: magaly.tribet@cea.fr

\section{Keywords}

SON68, glass alteration, iron, corrosion

\section{Abstract}

On the French disposal concept, the high level radioactive waste, contained in a glassy structure, is intended for a deep geological disposal. It is then important to understand glass alteration, which depends on the near-field materials and the environmental conditions. The carbon steel overpack corrosion (used in the French multi-barrier concept for the disposal of high level radioactive waste) could influence glass alteration by the release of iron in the solution and the formation of iron corrosion products. To better understand these interactions, different experiments were performed using a SON68 glass (non-radioactive surrogate of the R7T7 glass) 
separated by $80 \mu \mathrm{m}$ from a pristine iron foil. A pre-corroded iron foil and a PTFE foil, replacing the pristine iron foil, were also used. This study focus then on the influence of a pristine iron and a pre-corroded iron foil on glass alteration, and the influence of iron on a confined (inside de crack) and diluted (face exposed to the homogeneous solution) environment. Depending on the previously described conditions, some variations were observed: glass alteration increased in the presence of iron, as already observed in the literature. It was also higher in the diluted environment than in the confined environment, indicating that the gel protective properties were different in both environments. Pre-corrosion of an iron foil seemed to have no influence on glass alteration in a confined environment: glass alteration was the same even if an iron corrosion layer was formed at the surface of the pristine iron foil. 


\section{Introduction}

In France, the confinement of radionuclides in a borosilicate glass matrix is the chosen method for disposal of high level radioactive waste. This solution is based on a multi-barrier concept : glass incorporating in its structure the high level radioactive waste (Fission products and minor actinides) is poured in a stainless steel canister which will be contained in a carbon steel overpack of approximately $55 \mathrm{~mm}$ thick and intended for a deep geological disposal in the Callovo-Oxfordian (COx) claystone (ANDRA, 2005). Once the glass canister is disposed in the geological repository, alteration is expected to occur mainly when water will be in direct contact with the glass. This study focuses on this stage, which it is expected to have a greater impact on glass on the long term.

It has been reported that water will be in contact with the system after several hundreds to several thousand years, corroding the carbon steel overpack and altering the borosilicate glass. It has become a major scientific issue in radioactive waste management to understand the long-term evolution of glasses. It is then necessary to understand the interactions between glass iron and the solution to assess and model the performance of this glass.

At first, the environment in the deep geological disposal will be initially aerated. A first stage of corrosion of the materials will then take place in an aerated and dry environment. However, it has been predicted that the duration of this stage will last less than 100 years: oxygen will be actively consumed by corrosion of the materials and probably microbial activities and an anoxic environment will be insured (De Windt et al., 2014). When water will be in contact with the system, the corrosion of the steel overpack in a reductive environment could lead to the precipitation of iron oxides and 
iron carbonates such as magnetite, siderite, chukanovite and a considerable amount of iron release in the solution (Azoulay et al., 2013; Neff et al., 2005; Saheb et al., 2010).

Over the last decades, many studies have been performed to better understand glass alteration and the fundamental mechanisms that control glass dissolution in pure water have been identified (Frugier et al., 2008). At first, glass dissolution starts with hydration and interdiffusion, which induces an ion exchange between protons in the solution and alkali in the glass. This process creates a hydrated glass layer that dissolves by hydrolysis of the silicate network. Then, the hydrolysis rate decreases due to the reach of silicon saturation in the solution alongside the formation of a gel layer and the formation of secondary phases at the surface of the gel (Gin et al., 2011; Gin et al., 2017; Grambow, 1987; Van Iseghem et al., 2009). However, these processes depend on several factors such as the water composition, water renewal, the near-field materials and the host rock.

When water will be in direct contact with the glass, it will be at equilibrium with the near-field environment. It will be rich in cations and anions and its composition could impact glass alteration. It has been showed that in the hydrolysis process, cations in the solution react with the glass surface area creating Si-O-M sites (M represents the cations), weakening the Si-O bonds, which increases the hydrolysis rate an thus the alteration rate (Jollivet et al., 2012b). Moreover, once the gel formed, magnesium contained in the solution induces the formation Mg-silicates at the surface of the gel, which consumes silicon from the glass and increases glass alteration (De Echave et al., 2018; Fleury et al., 2013; Jollivet et al., 2012a; Neeway et al., 2011). Most of the magnesium precipitates in secondary phases and once all consumed, the alteration 
rate can reach a value close to the one observed in deionized water (Rolland et al., 2012).

Furthermore, near-field materials, such as the claystone and the carbon steel overpack, seem to alter the mechanisms already stablished. Indeed, iron and its corrosion products have been seen to enhance glass alteration. A first approach explaining this increase is the sorption of silicon on the corrosion products, such as magnetite, siderite and goethite (Godon et al., 2013; Jordan et al., 2007; Mayant et al., 2008; Michelin et al., 2013a). This phenomenon is limited over time by the saturation of the corrosion products surface sites (Philippini et al., 2006). A second approach is the precipitation of Fe-silicates at the surface of the gel (de Combarieu et al., 2011; Dillmann et al., 2016; Godon et al., 2013; McVay and Buckwalter, 1983). However, there is only few data in the literature concerning the nature of these secondary phases. Moreover, a third approach has also been considered: an iron incorporation into the gel layer. It has been suggested that iron could incorporate into the gel structure but most of the studies have shown that it incorporates into the gel porosity by precipitation of amorphous oxydrohydroxides or Fe-silicates (Dillmann et al., 2016; Michelin et al., 2013a; Michelin et al., 2013b; Rull et al., 2004). Nevertheless, the current literature reveals some gaps on those mechanisms and need to be confirmed to better predict the long term behaviour of nuclear glass.

The aim of this study is to provide further information about glass alteration in the presence of metallic iron as a model system. The leaching experiment was then carried-out using a SON68 glass (non-radioactive surrogate of the R7T7 glass, the industrial French glass for high-level radioactive waste) separated by $80 \mu \mathrm{m}$ from an iron foil (pristine or pre-corroded) in the Callovo-Oxfordian groundwater in an anoxic environment. This study allows to compare the influence of iron on glass alteration in 
a confined environment, inside the crack, and in a diluted environment, face exposed to the homogeneous solution. Furthermore, information about the effect of iron precorrosion on glass alteration is provided. 


\section{Materials and methods}

\subsection{Experimental Setup}

\subsubsection{Glass sample}

The SON68 glass was prepared by fusion of a mixture of oxides at $1150 \stackrel{\circ}{\mathrm{C}}$ for 3 hours. Its composition is given in Table 1. The melted glass was then introduced into graphite crucibles of $2.5 \times 2.5 \mathrm{~cm}^{2}$ section and annealed for 2 hours at $520 \stackrel{\circ}{ } \mathrm{C}$. A glass density of $2.75 \pm 0.03{\mathrm{~g} . \mathrm{cm}^{-3}}^{-3}$ was obtained by hydrostatic weighing. The glass ingots were cut with a diamond saw into coupons of $2.5 \times 2.5 \times 0.2 \mathrm{~cm}^{3}$. Each face of each coupon was polished to a glass surface roughness less than $1 \mu \mathrm{m}$. The polished coupons were then cut in half with a dicing saw. All coupons were ultrasonically cleaned in acetone and then in absolute ethanol. The geometric surface area of each glass coupon was $6.8 \pm 0.2 \mathrm{~cm}^{2}$.

\subsubsection{Leaching experiments}

The experimental setup was composed of model crack samples leached at $90^{\circ} \mathrm{C}$ in individual cells in the synthetic Callovo-Oxfordian clay-based groundwater solution (called then COx groundwater). The leaching solution was prepared from the COx groundwater composition at equilibrium with the clay rock calculated by the BRGM (French Geological Survey) (Gaucher et al., 2009). Its chemical composition is presented in Table 2. This solution was obtained by a mixture of different salts at 
different concentrations in deionized water. The $\mathrm{pH}$ was adjusted to a value of 6.36 at room temperature by $\mathrm{CO}_{2}$ bubbling when all salts were dissolved. Then it was deaerated by $\mathrm{CO}_{2}$ bubbling with $3000 \mathrm{ppm}$ for one hour to eliminate the oxygen dissolved in the solution.

Three series of model crack samples were made. They consisted of one SON68 glass monolith, measured $2.5 \times 1.2 \times 0.1 \mathrm{~cm}^{3}$ and one metallic iron foil of $2.5 \times 1.2 \times 0.0125 \mathrm{~cm}^{3}$ (99.99\% purity, Goodfellow) (Figure 1). Two of the model cracks contained a pure iron foil and one sample contained a pre-corroded iron foil replacing the pure iron foil. The pre-corroded iron foil was obtained by introducing a pure iron foil in the $\mathrm{COx}$ groundwater solution at $90 \stackrel{\circ}{ } \mathrm{C}$. After 30 days, the pre-corroded iron foil was extracted and used to prepare the glass-pre-corroded iron sample. Once the model crack was assembled, the sample constituted by a glass coupon-pre-corroded iron foil was introduced in the same solution where the iron foil was pre-corroded and it was then leached for 14 days.

The model crack is presented on Figure 1 and its preparation is detailed as follow. The two materials were separated by two PTFE (PolyTetraFluoroEthylene) threads of a diameter of $80 \mu \mathrm{m}$. A small amount of high temperature silicone instant gasket was introduced between both materials to ensure that they will stick together. This spacing favors the interaction between both materials and was defined as the confined environment. The external sides open to the solution were defined as the diluted environment. In each case, the system contained a model crack sample introduced in a stainless-steel vessel sustained in a Teflon basket and leached in 30 $\mathrm{mL}$ of the COx solution. All these leaching experiments were performed under anoxic conditions, in a glovebox under nitrogen atmosphere $\left(\mathrm{P}\left(\mathrm{O}_{2}\right)<10 \mathrm{ppm}\right)$. 
Samples were altered in the cells for 14 days and 105 days when the pristine iron foil was used, and for 14 days when the pre-corroded iron foil was used. A blank experiment was also carried out for 14 days where iron was replaced by a PTFE foil (inert material for glass alteration). At the end of each experiment, samples were extracted in the glovebox, dried at room temperature for 3 days and then embedded together with a very fluid epoxy resin.

\subsection{Analytical techniques}

\subsubsection{Leachate analysis}

In this case solution analysis allowed to obtain a global approach of glass alteration in the presence of iron. The $\mathrm{pH}$ of the leachate was measured at the end of each experiment at room temperature with an uncertainty measurement of \pm 0.1 . The leachate was analyzed by an ICP-AES Jobin Yvon JY66 system after acidification with ultra-pure grade $\mathrm{HNO}_{3}$ at the beginning and the end of the experiment. Concentrations of $\mathrm{Si}, \mathrm{B}, \mathrm{Li}, \mathrm{Ca}, \mathrm{Na}, \mathrm{Fe}$ and $\mathrm{Mg}$ were determined. The analytical uncertainty was $\pm 3 \%$. Chlorides and sulfates were also analyzed with a Metrosep A Supp 16 ionic chromatography device to follow closely the concentrations of these elements. The analytical uncertainty was $\pm 10 \%$.

\subsubsection{Solid characterization}


The pristine iron foil was observed both directly and at the edge after embedding. All embedded samples were polished to a micron roughness and the surface of the polished cross sections were coated with carbon for observations and chemical analysis. Samples were first characterized by Scanning Electron Microscopy (SEM) coupled with an energy dispersive X-ray spectrometer device (EDS) with an environmental scanning electron microscope on a FEI Quanta 200 ESEM FEG microscope (partial pressure of $90 \mathrm{~Pa}$, high tension between 3 and $15 \mathrm{kV}$ ) at the Marcoule Institute for Separative Chemistry (France).

The pre-corroded iron foil as the polished cross section were also analyzed by microRaman spectroscopy using a Horiba Jobin-Yvon Xplora plus $\mu$-Raman spectrometer coupled with a microscope. The excitation laser used was of $532 \mathrm{~nm}$ (green) focused on a $0.7 \times 0.7 \mu \mathrm{m}^{2}$ spot and collected through an $\times 100$ objective. The laser power used was of $1.4 \mathrm{~mW}$, low enough to avoid any iron oxidation (Neff, 2003).

Moreover, in order to study samples at a nanometer scale, a thin foil with a thickness of approximately $100 \mathrm{~nm}$ was prepared by a Focused-lon Beam (FIB) technique with a dual-beam SEM/FIB microscope (LYRA GM TESCAN) at Tescan Analytics (Fuveau, France). Transmission Electron Microscopy (TEM) coupled with an energy dispersive X-ray Spectrometer Device (EDS) analysis were performed with a JEOL 2010F microscope at CP2M (Marseille, France) on the thin foil. 


\section{Results}

\subsection{Solution analysis}

The solution was analyzed at the beginning and the end of the pre-corrosion of the iron foil and the model crack samples experiments (Table 3). These results represent only the bulk solution composition and do not give information about possible interactions in the confined environment between the glass and the iron foil nor exactly about the alteration in the diluted environment.

After pre-corrosion of the iron foil, it was observed that the silicon concentration in the COx groundwater decreased as the iron concentration increased. However, $\mathrm{Mg}, \mathrm{Ca}$ and $\mathrm{Sr}$ concentrations remained around the same value as the initial solution. It is important to highlight that the $\mathrm{pH}$ value does not change significantly at the end of the iron pre-corrosion. When the cells were opened, it was possible to observe some precipitates in the solution. The iron foil aspect changed, which is in good agreement with the Fe release observed from the solution analysis indicating that iron corrosion occurred.

Concerning the model cracks experiments, when glass and iron were both present in the system, B, Li and $\mathrm{Na}$ concentrations increased. Since these three elements are mobile and soluble elements from the glass and are used as glass alteration tracers, these results confirmed that glass was altered significantly under these conditions. Some variations were also observed in $\mathrm{Si}, \mathrm{Ca}$ and Fe concentrations as an increase of $\mathrm{pH}$ values. The $\mathrm{pH}$ increase (around $0.8 \mathrm{pH}$ unit) was the same when a Teflon foil, replacing the iron foil, was used. However, the $\mathrm{pH}$ value was higher when the iron foil 
was first pre-corroded (difference of $1 \mathrm{pH}$ unit). On the blank experiment, which corresponds to a glass coupon altered in COx groundwater without an iron source, the concentration of these tracers elements were under the detection limit $(<0.5$ $\mathrm{mg} \cdot \mathrm{L}^{-1}$ for boron and lithium concentrations). This indicates that glass is more altered when there is an iron source in the system. It was also possible to observe on the blank experiment an increase on the silicon concentration contrary to the systems containing an iron source. Moreover, the $\mathrm{pH}$ value is the same as the one observed in the sample containing a pristine iron foil, the $\mathrm{pH}$ is then controlled by glass

alteration. A small amount of iron was observed on the blank experiment which could be associated with an impurity in the stainless-steel vessel. Moreover, it can be highlighted that magnesium concentrations had no significant variations, even if $\mathrm{pH}$ values were able to favor Mg silicates precipitation under these conditions (Jollivet et al., 2012a).

\subsection{Solid characterizations}

3.2.1. Pre-corrosion of the Iron foil

SEM observations of the surface of the pre-corroded iron foil displayed 3 different phases (defined as cubes, sticks and sheets) and a corroded surface layer (Figure 2). EDS analyses showed that the layer composed by the corroded iron surface contained mainly $\mathrm{Fe}, \mathrm{Si}$ and $\mathrm{O}$. The cubes contained a mixture of $\mathrm{Fe}, \mathrm{O}$ and $\mathrm{Ca}$, the sticks contained mainly $\mathrm{Ca}$ and $\mathrm{O}$ and the sheets contained mostly $\mathrm{Si}$ and Fe. EDS analysis on the polished cross section of the pre-corroded iron foil confirmed the 
surface analysis. Moreover, global observations of the cross section showed that the corrosion layer appears to be cracked (Figure 2). This layer is inhomogeneous all along the iron foil. Using different images, a corrosion thickness of approximately 16 $\pm 3 \mu \mathrm{m}$ was determined. The pristine iron foil had an initial thickness of about $125 \pm 3$ $\mu \mathrm{m}$. After pre-corrosion, this value varied from $80 \mu \mathrm{m}$ to $120 \mu \mathrm{m}$ depending on the observed area.

Raman Spectroscopy was also performed at different spots at the surface of the iron foil. It was possible to distinguish two different spectra: one from the sticks and another from the corroded surface layer (Figure 2). It was not possible to use this technique to identify the sheets and cubes structures since it was difficult to differentiate them using the microscope. The corroded surface layer Raman spectrum was identified as siderite. It was possible to obtain its spectra since it is stable under the laser power. The main bands matches with published siderite bands (Hanesch, 2009) : the 184, 287 and $731 \mathrm{~cm}^{-1}$ bands and the more intensive at 1085 $\mathrm{cm}^{-1}$, concerning the $\mathrm{C}-\mathrm{O}$ bond. Concerning phases named as sticks, the Raman spectrum obtained was identified as aragonite, a calcium carbonate with an orthorhombic crystal system. The aragonite Raman spectrum is complex, and it has been published that it has 30 different bands with different intensities (De La Pierre et al., 2014). The Raman spectrum presented in here shows 13 of these bands: at 111, $178,246,258,700,703,715,852,1462$ and $1575 \mathrm{~cm}^{-1}$, two intensive bands at 151 and $204 \mathrm{~cm}^{-1}$ and the most intensive band at $1080 \mathrm{~cm}^{-1}$, concerning the $\mathrm{C}-\mathrm{O}$ band.

\subsubsection{Glass alteration in the presence of iron}


The glass coupons were altered in the presence of a pre-corroded iron foil for 14 days and in the presence of a pristine iron foil for 14 and 105 days in the same conditions. Results at the end of each experiment are presented as followed. A blank experiment, replacing iron by a Teflon foil was also performed. In this last case, SEM results are not presented in this paper since the alteration layer was too thin to be observed using this technique (glass alteration thickness $<300 \mathrm{~nm}$ ). This result is in good agreement with the absence of glass tracer elements in the solution over the detection limit. It can thus be clearly assumed that the glass alteration is higher when glass is altered in the presence of iron.

\section{Impact of pre-corrosion of the iron foil}

When the pre-corroded iron foil was used, it was possible to observe by SEM analysis an alteration layer on the glass phase and two different corrosion layers (corrosion products + secondary phases) on the iron foil. Some secondary phases were also observed (Figure 3).

The alteration layer was highlighted using backscattering electrons due to its depletion in alkaline and alkaline earth elements. It was observed that at the edges, the glass alteration was larger. This could be due to a higher renewal of the solution at the edges increasing then glass alteration (Chomat et al., 2012). These observations are in good agreement with results presented by Dillmann et al. (Dillmann et al., 2016). In the confined environment, at the center of the sample, it was possible to measure the thickness of the glass alteration layer using different images. All measurements were made using only SEM images assuming an 
isovolumetric glass alteration. All results are summarized in Table 4. For the glasspre-corroded iron foil sample, an average value of approximately $1.3 \pm 0.4 \mu \mathrm{m}$ was obtained. However, in the diluted environment, the average value obtained was of approximately $2.3 \pm 0.3 \mu \mathrm{m}$. These different values could suggest that, in the confined environment, silica concentration in the solution was higher than in the diluted environment.

Moreover, EDS results showed that the glass alteration was depleted in alkali such as $\mathrm{Na}$ and enriched with Fe. Moreover, some rare earth precipitates enriched in La, $\mathrm{Nd}$ were also observed all along the alteration layer. At the surface of the alteration layer, some secondary phases rich with $\mathrm{Fe}$ and $\mathrm{Si}$ were also observed.

On the iron phase, it was possible to notice by SEM analysis two different corrosion layers. (Figure 3). The layer next to the pristine iron foil was identified as the corroded layer formed during the pre-corrosion of the iron foil. It was rich with $\mathrm{Ca}$ and $\mathrm{Fe}$ and some traces of $\mathrm{Si}$. The second layer, closer to the glass, was defined as secondary phases which were also rich with $\mathrm{Si}, \mathrm{Ca}$ and $\mathrm{Fe}$. These phases, containing elements from the solution and the glass, were also formed at the surface of the glass.

Furthermore, the iron surface exposed to the diluted environment was more corroded than the one exposed to the glass. Some precipitates, rich with $\mathrm{Ca}$ or $\mathrm{Si}$ and $\mathrm{Fe}$, also reached the glass assuming that there could be a higher consumption of silicon on this area. However, no difference was observed on glass alteration thickness when secondary phases reached the glass.

Using a pristine iron foil, after 14 days of leaching, SEM analysis showed similar results than the glass-pre-corroded iron sample (Figure 3): an alteration layer on the glass and the formation of precipitates on the iron phase. However, only one corrosion layer was observed on the iron foil. Under these conditions, using different 
images, the thickness of the alteration layer in the confined environment at the centre of the sample was $1.3 \pm 0.3 \mu \mathrm{m}$. This value is the same as the one observed when the pre-corroded iron foil was used. This could indicate that the pre-corrosion of the iron foil did not have an influence on glass alteration.

Moreover, the alteration layer in the diluted environment was of approximately $3.6 \pm$ $0.5 \mu \mathrm{m}$, higher than the one formed when the pre-corroded iron foil was used. As seen in the previous case, when secondary phases formed at the surface of the iron foil reached the glass, no difference on glass alteration thickness was observed. In conclusion, under these conditions, there was no significant differences highlighted whether the iron source was pre-corroded or not.

\section{Impact of leaching duration}

Characterizations at the nanoscale on the altered glass of the 14 days glass-pristine iron foil sample were also performed. TEM observations showed that iron is present in all the alteration layer. However, its quantity decreased from the outer layer to the pristine glass (Figure 4). EDS analysis also highlighted a thin layer enriched with $\mathrm{Mg}$ in the gel, indicating a possible incorporation of $\mathrm{Mg}$ in the alteration layer or the formation of Mg-Si secondary phases. Moreover, the alteration layer was composed of two distinct areas. There was a first dense layer, next to the pristine glass, depleted in $\mathrm{Na}, \mathrm{Si}$ and $\mathrm{Al}$ and enriched with Fe. Both its morphology and its composition suggest that this is the gel zone. There is also a second zone, containing sticks and sheets, rich with $\mathrm{Si}$ and Fe. This could be suggested as the secondary phases area which is formed at the surface of the gel. 
Concerning the secondary phases, the sticks were rich with $\mathrm{Fe}$ and $\mathrm{Si}$ with some traces of $\mathrm{Mg}$ and with a $\mathrm{Fe} / \mathrm{Si}$ ratio of 1.76. The sheets were also rich with $\mathrm{Si}$ and $\mathrm{Fe}$ but with some traces of $\mathrm{Na}, \mathrm{Mg}, \mathrm{Ca}, \mathrm{Mo}$ and a Fe/Si ratio of 1.1. This could indicate the formation of two different Fe-Si secondary phases.

After 105 days of leaching, SEM analysis on the glass-pristine iron foil sample allowed to identify, in the confined environment, a glass alteration thickness at the centre of the sample of $2.2 \pm 0.4 \mu \mathrm{m}$, thicker than the 14 days glass-pristine iron foil sample (Figure 3 and Table 4). This means that even if a passivating layer was formed, the alteration of the glass increased versus time. In the diluted environment the thickness of the glass alteration layer was of approximately $8.0 \pm 0.7 \mu \mathrm{m}$, twice higher than the 14 days sample, also confirming that glass alteration increased versus time.

EDS results showed that there is also an important amount of $\mathrm{Fe}$ and $\mathrm{Mg}$ incorporated in the alteration layer. As seen in the 14 days leaching experiment, the iron incorporation decreased from secondary phases to the pristine glass. In the 105 days sample, the $\mathrm{Mg}$ incorporation is all along the alteration layer. No concentration at the surface of the gel was observed, as seen in the 14 days sample.

Under these conditions, the quantity and size of secondary phases were also higher than the 14 days sample: in the diluted environment as in the confined environment. Secondary phases were rich with $\mathrm{Si}$ and $\mathrm{Fe}$, and some others rich with $\mathrm{Ca}$. However, using only SEM images it was not possible to observe in the 105 days sample the two different morphologies of secondary phases observed by TEM analysis on the 14 days sample. Moreover, some rare earth precipitates were formed in the alteration layer. After 105 leaching days, these precipitates are larger than those observed in the 14 days sample. 
These results displayed that the glass alteration as the iron corrosion increased versus time. Moreover, it appeared that the size and amount of the precipitates formed under these conditions also increased versus time without changing its morphology. 


\section{Discussion}

In this study, it was observed that glass alteration increases in the presence of an iron source. Comparing results after 14 days of leaching using a pristine iron foil or a pre-corroded iron foil, the glass alteration thickness was of approximately $1.3 \mu \mathrm{m}$ in the confined environment for both experiments. However, in the diluted environment, the alteration thickness was different, of approximately $2.3 \mu \mathrm{m}$ when a pre-corroded iron foil was used, and of approximately $3.6 \mu \mathrm{m}$ when the pristine iron was used. Moreover, comparing results using only a pristine iron foil, it was observed that glass alteration increased versus time. From 14 days of leaching to 105 days, in the confined environment, the increase of the glass alteration was from $1.3 \mu \mathrm{m}$ to $2.2 \mu \mathrm{m}$ and, in the diluted environment, the increase of the alteration layer was from $3.6 \mu \mathrm{m}$ to $8 \mu \mathrm{m}$.

This increase of glass alteration in the presence of an iron source has already been reported in the literature and different mechanisms have been proposed to explain it (Godon et al., 2013; Michelin et al., 2013a) : precipitation of Fe-Si secondary phases, incorporation of iron in the gel and sorption of silicon on iron corrosion products. Moreover, the use of a synthetic COx solution could also induce the precipitation of Mg-Si secondary phases, increasing also glass alteration (Debure et al., 2012;

Debure et al., 2013; Fleury et al., 2013; Jollivet et al., 2012a). In the presence of corrosion products, it has been proposed that when glass is altered, a thicker glass alteration layer is formed than when pure iron is used (Rébiscoul et al., 2013). However, under the experimental conditions presented in the present study, the use of a pre-corroded iron foil instead of a pristine iron foil gave no significant difference. One may wonder the reason for these similarities. Under the present experimental 
conditions, an iron incorporation in the gel has been observed, but how does this incorporation take place in these systems? Furthermore, if iron is involved in the precipitation of Fe-Si secondary phases, what are these secondary phases? These different points will be discussed as followed.

\subsection{Iron corrosion and its impact on glass alteration}

Under the present experimental conditions in an anoxic environment, the main corrosion product obtained was siderite. This is in good agreement with data from the literature under similar experimental conditions (Neff et al., 2005; Romaine et al., 2013; Saheb et al., 2010). No other iron oxides or iron carbonates were characterized in our system. However, in similar conditions, chukanovite could also precipitate (Chaou et al., 2014; Michelin et al., 2015; Odorowski et al., 2017; Saheb et al., 2010), but it has not been observed in this study. It is important to highlight that under the experimental conditions presented in this paper, no calcite was observed as presented in previous studies (Dillmann et al., 2016; Schlegel et al., 2014; Schlegel et al., 2016). Instead, aragonite was identified as the main calcium carbonate, with a orthorhombic crystal system (De La Pierre et al., 2014). Calcium carbonates can precipitate in different crystalline structures such as calcite, aragonite, vaterite. Aragonite can be formed at temperature superior to $50^{\circ} \mathrm{C}$ and seems to be more stable than others calcium carbonates (Wray and Daniels, 1957) which is in agreement with the present experimental conditions $\left(90^{\circ} \mathrm{C}\right)$.

The pre-corrosion of an iron foil for 30 days led to a partial corrosion of the iron foil: the pristine iron foil was covered by iron corrosion products all along its surface. 
Previous studies have shown that when only iron corrosion products are used, such as magnetite or siderite, the increase of glass alteration is less significant than when metallic iron is used (Michelin et al., 2013a; Rébiscoul et al., 2013). Therefore, according to the literature, in the confined environment, when the glass-pre-corroded iron model crack was used, glass alteration should have been controlled only by the iron corrosion products and it should have been lower than in the glass-pristine iron foil model crack. However, the thickness of the glass alteration layer was the same in both cases (approximately $1.3 \mu \mathrm{m}$ ). It seemed that, in the systems presented here, iron availability in the solution was the same in both cases. Since the iron corrosion layer appeared to be cracked and inhomogeneous all along the surface of the pristine glass, no protective layer at the surface of the iron foil was formed, inducing a direct contact between the pristine iron and the solution during all the leaching duration: pristine iron controlled then the iron release in the solution in both experiments.

In the literature, it has also been reported that when iron corrosion products such as magnetite or siderite are used, sorption of silicon could take place with a limited impact (Godon et al., 2013; Michelin et al., 2013a; Neill et al., 2017; Philippini et al., 2006). This could have been observed in the glass-pre-corroded iron sample. However, it was not possible to observe any silicon sorption from the solid characterizations used in this study. This mechanism was certainly negligible compared to other mechanisms taking place at the time.

Furthermore, a difference between the thickness of the alteration layer in the diluted environment was observed: the alteration thickness was greater when a pristine iron foil was used than when a pre-corroded iron foil was used $(2.3 \mu \mathrm{m}$ compared to 3.5 $\mu \mathrm{m}$ after 14 leaching days). However, it can be noticed that before preparing the 
glass-pre-corroded iron model crack, the iron foil was first introduced for 30 days in the COx solution: an equilibrium between the solution and the iron foil could have taken place. After 14 days of leaching, the $\mathrm{pH}$ bulk of the glass-pre-corroded iron

sample was 8.1 , contrary to the glass-pristine iron model crack sample, where the $\mathrm{pH}$ bulk was first 7.1. In the literature, it has been shown that glass alteration depends on the $\mathrm{pH}$ value (Gin and Mestre, 2001): when the $\mathrm{pH}$ value decreased, the passivating properties of the gel also decreased, increasing then glass alteration. The difference on the thickness of the glass alteration layer could thus be related to the $\mathrm{pH}$ value: in the diluted environment it can be assumed that a more passivating glass alteration layer was formed when the pre-corroded iron foil was used $(\mathrm{pH}=8.1)$ than when a pristine iron foil was used $(\mathrm{pH}=7.1)$.

\subsection{Glass alteration versus time}

The glass alteration thickness of each sample was measured from different SEM images. If the glass was altered at its initial rate in the COx groundwater, the thickness of the altered glass can be calculated using the forward dissolution rate determined by Jollivet et al. of $r_{0}=1.7 \mathrm{~g} \cdot \mathrm{m}^{-2} \cdot \mathrm{d}^{-1}$ (Jollivet et al., 2012b). With such an alteration rate, after 14 days of leaching, these calculations lead to a glass alteration layer of approximately $9 \mu \mathrm{m}$, and after 105 days of leaching, of approximately $66 \mu \mathrm{m}$. Even when iron was present in the system and led to an increase of glass alteration, theses alteration thicknesses were not reached. These results showed thus that glass alteration reached at least the drop alteration rate regime and are in good agreement with the formation of a protective gel layer. 
In all samples, the thickness of the alteration layer was different in the confined environment and in the diluted environment. These observations could be related to the local solution characteristics. In the confined environment, the local transport of water could be controlled by diffusion and the solution was poorly renewed (Chomat et al., 2012; Dillmann et al., 2016). In the diluted environment, no saturation of silica concentration was observed in the bulk solution, as it can be qualitatively observed from solution analysis (Table 3). Since the passivating properties of the gel depends on local physical-chemical conditions, it can then be though that there was a higher silica concentration in the solution at the centre of the crack, enabling the formation of a more passivating gel layer than in the diluted environment (Pèlegrin et al., 2010; Rebiscoul et al., 2005).

Furthermore, comparing results on the glass alteration thickness after 14 days and 105 days of leaching, it is worth noting that the thickness of the glass alteration layer increased versus time in both environment (Figure 5). Even though, in this study, it was possible to compare only two different leaching times, it is possible to highlight that the glass alteration rate also decreased versus time: after 91 days of leaching, in both environments the glass alteration layer was twice times thicker. This could suggest that, even with an unlimited iron source, a protective gel was formed decreasing glass alteration over time.

The passivating properties of the gel could be affected by the incorporation of iron or magnesium in the gel layer (Rebiscoul et al., 2004; Rull et al., 2004). This incorporation could be explained as followed: precipitation of nanometric secondary phases in the gel pores or the incorporation of these two elements in the glass alteration layer as charge compensator for $\mathrm{AlO}_{4}{ }^{-}$and $\mathrm{ZrO}_{6}{ }^{2-}$, such as in the case of Ca (Chave et al., 2011; Mercado-Depierre et al., 2013; Thien et al., 2012). In a 
previous study, similar to the one presented in this paper, where two SON68 monoliths separated by an iron source where altered in the COx groundwater, it was observed that the iron incorporation is due of an incorporation of Fe-Si precipitates in the gel pores, in the form of greenalite (Dillmann et al., 2016). Moreover, in another study, using a simple glass and with $\mathrm{FeCl}_{2}$ constant additions in the solution, it has been proposed that there could be both incorporation into the gel structure, near the pristine glass, and precipitation of secondary phases in the gel pores, near secondary phases (Aréna et al., 2018). If there was an incorporation of Fe-silicates in the gel pores, an important amount of these secondary phases could clog these pores increasing the passivating properties of the gel (Jollivet et al., 2008; Michelin et al., 2013b). In this study, it was possible to see that the amount of iron decreased from secondary phases to the pristine glass: from approximately $15 \mathrm{~mol} . \%$ in secondary phases to $9 \mathrm{~mol} . \%$ in the gel and $0.7 \mathrm{~mol} . \%$ in the pristine glass which is in good agreement with the theoretical SON68 composition ( $\mathrm{Fe}=0.8 \mathrm{~mol} . \%$ in the glass). Iron must have been mostly provided by the solution but it could also have been provided by the glass. Nevertheless, with the analytical techniques used in this study, it was not possible to identify if there was an incorporation of iron into the gel structure or if there was a precipitation of secondary phases into the gel pores. However, using TEM analysis results, a regular decrease of iron in the glass alteration layer lead to consider an iron diffusion into the alteration layer instead of a precipitation of iron secondary phases.

It is not yet certain how iron incorporates into the gel, but it can be confirmed by the important amount of Fe-Si secondary phases formed at the surface of the gel, that its precipitation could be the main source of the increase of glass alteration in the presence of an iron source. 


\subsection{Precipitation of secondary phases}

Previous studies have shown that glass alteration processes are mainly associated with the precipitation of secondary phases (Burger et al., 2013; Fleury et al., 2013; Inagaki et al., 1996; Jollivet et al., 2012a; Michelin et al., 2013b). The precipitation of Fe-silicates or Mg-silicates increases silicon consumption, decreasing the gel passivating properties. It sustains glass dissolution and it can then be considered as a major driving force behind glass alteration.

\subsubsection{Fe-silicates}

This phenomenon has been verified in the present systems: Fe-silicates were formed in every sample containing an iron source. These secondary phases were located mainly at the surface of the gel or near the iron corrosion products. On a recent study with a simplified glass, it has been suggested that the Fe-silicates formed are phyllosilicates belonging to the smectite group (Arena et al., 2017; Burger et al., 2013; Schlegel et al., 2016). Moreover, another recent study using SON68 glass model cracks with an iron source incorporated in the aperture of the model crack, has shown that phyllosilicates, such as nontronite and greenalite, are formed at the surface of the gel, or in the gel pores (Dillmann et al., 2016). Under the experimental conditions presented here, from TEM-EDS analysis, it was not possible to identify these phases. However, two different structures of Fe-silicates at the surface of the gel were observed: one containing a Fe/Si ratio of 1.1 with a small concentration of 
$\mathrm{Na}$ and traces of $\mathrm{Mg}, \mathrm{Ca}$ and another containing a Fe/Si ratio of 1.76 with traces of only $\mathrm{Na}, \mathrm{Mg}$. The different $\mathrm{Fe} / \mathrm{Si}$ ratios and morphologies suggest thus that, under the present experimental conditions, two different Fe-silicates precipitated.

\subsubsection{Mg-silicates}

In previous studies, when there is a magnesium source, precipitation of Mg-silicates has also been observed (Debure et al., 2012; Fleury et al., 2013; Jollivet et al., 2012a). There is a pH threshold value above which its precipitation is possible: at $90^{\circ} \mathrm{C}$ it has been proposed to be at $\mathrm{pH}=6.5$ (Jollivet et al., 2012a). The $\mathrm{pH}$ values, obtained under the experimental conditions presented in this paper, were above the $\mathrm{pH}$ threshold value, favouring then Mg-silicate precipitation. Results on solution analysis showed no significant consumption of magnesium leading to the assumption that there was no significant Mg-silicate precipitation. However, EDS analysis highlighted a magnesium incorporated in the glass alteration layer. For the glass-iron foil 14 days sample, TEM-EDS analysis showed a small amount of $\mathrm{Mg}$ incorporation and it was concentrated at the surface of the gel. However, on the glass-iron foil 105 days sample, an incorporation of $\mathrm{Mg}$ all along the alteration layer was highlighted by SEM analysis. This could indicate that Mg diffused slowly versus time from the solution into the gel. In both cases, the amount of $\mathrm{Mg}$ incorporated into the alteration layer was under $2 \mathrm{~mol} . \%$, indicating that there was a small consumption of $\mathrm{Mg}$ and explaining why no significant differences were observed on $\mathrm{Mg}$ concentration in the solution (Table 3). It is important to highlight that, under the present experimental conditions, the precipitation of Fe-silicates is then highly favoured than the precipitation of $\mathrm{Mg}$-silicates. 


\section{Conclusion}

The aim of the present study was to investigate the SON68 glass alteration behaviour, in a synthetic groundwater, in the presence of an iron source under anoxic conditions. The influence of the iron source was studied using pure iron and a precorroded iron foil, and two different environments were also compared: a confined (inside de crack) and diluted (face exposed to the homogeneous solution) environment. All results are consistent between them.

Pre-corrosion of an iron foil led to a partial iron corrosion: a crack and inhomogeneous corrosion layer was formed at the surface of the pristine iron. Iron corrosion led mainly to the precipitation of iron carbonates and calcium carbonates, where siderite and aragonite were identified. The pre-corrosion of the iron foil seemed to have no significant influence on glass alteration in the confined environment: there was the same iron availability in the solution in both systems (precorroded iron foil or pristine iron foil, 14 days).

In all conditions (iron pre-corrosion or not, alteration duration), a difference between both environments was also highlighted. In the diluted environment, glass alteration was higher than in the confined environment. It seemed that a more protective gel was formed in the confined environment than in the diluted environment indicating that glass alteration depended on local physico-chemical conditions. Moreover, it is worth noting that, in both environments, the glass alteration rate decreased versus time: the passivating properties of the gel increased then versus time.

This study confirms that glass alteration is higher in the presence of an iron source than without any iron source in both environments. The main processes observed in 
this study were the incorporation of iron in the gel formed by glass alteration and the precipitation of Fe-Si secondary phases both on the surface of the gel and the iron foil. The iron concentration in the gel diminished from secondary phases to the pristine glass indicating that iron was mainly provided by the solution. Secondary phases were observed in all experiments containing an iron source, and they were mainly composed with iron and silicon. Two different Fe-Si phases were differentiated in terms of morphology and Si/Fe ratio but with the techniques proposed in this study, it was not possible to identify them.

Further experiment of the measurement of the iron ratio $\mathrm{Fe}(\mathrm{II}) / \mathrm{Fe}(\mathrm{III})$ must be performed along all the alteration layer in order to provide more information about the iron incorporation. This information could point out if iron was provided by the glass (incorporated as $\mathrm{Fe}(\mathrm{III})$ ) or by the iron foil (Fe(II) in anoxic conditions). Moreover, in order to provide more data for modelling programs and better understand the longterm behaviour of nuclear glass under disposal conditions, it is necessary to acquire information about the nature and crystallinity of the secondary phases formed, containing both Si and Fe, which are involved as the main mechanism responsible for the increase of glass alteration in the presence of an iron source. These results allow to have a first approach about the alteration of a SON68 glass separated by $80 \mu \mathrm{m}$ from an iron source. More experiments will be carried out with a a-doped SON68 glass ( $\alpha$ mean range in water of $40 \mu \mathrm{m}$ ) to better understand the influence of an $\alpha$ irradiation on the alteration of a nuclear glass under environmental conditions. 


\section{Acknowledgements}

The authors are grateful to the CEA for their financial support. We would like to thank also Tescan Analytics (Fuveau, France) for the FIB cross section, and Martiane CABIE of CP2M (Marseille, France) for the TEM analysis. 


\section{References}

ANDRA, 2005. Dossier 2005 : Argile, Évaluation de la faisabilité du stockage géologique en formation argileuse.

Arena, H., Godon, N., Rebiscoul, D., Frugier, R., Podor, R., Garces, E., Cabie, M., Mestre, J.P., 2017. Impact of iron and magnesium on glass alteration:

Characterization of the secondary phases and determination of their solubility constants. Applied Geochemistry 82, 119-133.

Aréna, H., Godon, N., Rébiscoul, D., Podor, R., Garcès, E., Cabie, M., Mestre, J.P., 2018. Impact of $\mathrm{Fe}, \mathrm{Mg}$ and $\mathrm{Ca}$ elements on glass alteration: Interconnected processes. Geochim. Cosmochim. Acta submitted.

Azoulay, I., Conforto, E., Refait, P., Rémazeilles, C., 2013. Study of ferrous corrosion products on iron archaeological objects by electron backscattered diffraction (EBSD). Applied Physics A 110, 379-388.

Burger, E., Rebiscoul, D., Bruguier, F., Jublot, M., Lartigue, J.E., Gin, S., 2013. Impact of iron on nuclear glass alteration in geological repository conditions: A multiscale approach. Applied Geochemistry 31, 159-170.

Chaou, A.A., Abdelouas, A., Mendili, Y.E., Bouakkaz, R., Martin, C., 2014. The French SON68 Glass Vapor Hydration under Different Atmospheres. Procedia Materials Science 7, 179-185.

Chave, T., Frugier, P., Gin, S., Ayral, A., 2011. Glass-water interphase reactivity with calcium rich solutions. Geochimica Et Cosmochimica Acta 75, 4125-4139. 
Chomat, L., Bouyer, F., Gin, S., Roux, S., 2012. Effect of leaching-driven flow on the alteration kinetics of an ideal crack in SON68 glass. Journal of Nuclear Materials 426, 160-172.

de Combarieu, G., Schlegel, M.L., Neff, D., Foy, E., Vantelon, D., Barboux, P., Gin, S., 2011. Glass-iron-clay interactions in a radioactive waste geological disposal: An integrated laboratory-scale experiment. Applied Geochemistry 26, 65-79.

De Echave, T., Tribet, M., Jollivet, P., Marques, C., Gin, S., Jégou, C., 2018. Effect of clayey groundwater on the dissolution rate of SON68 simulated nuclear waste glass at $70{ }^{\circ} \mathrm{C}$. Journal of Nuclear Materials, Submitted.

De La Pierre, M., Carteret, C., Maschio, L., Andre, E., Orlando, R., Dovesi, R., 2014. The Raman spectrum of $\mathrm{CaCO} 3$ polymorphs calcite and aragonite: A combined experimental and computational study. Journal of Chemical Physics 140.

De Windt, L., Marsal, F., Corvisier, J., Pellegrini, D., 2014. Modeling of oxygen gas diffusion and consumption during the oxic transient in a disposal cell of radioactive waste. Applied Geochemistry 41, 115-127.

Debure, M., Frugier, P., De Windt, L., Gin, S., 2012. Borosilicate glass alteration driven by magnesium carbonates. Journal of Nuclear Materials 420, 347-361.

Debure, M., Frugier, P., De Windt, L., Gin, S., 2013. Dolomite effect on borosilicate glass alteration. Applied Geochemistry 33, 237-251. 
Dillmann, P., Gin, S., Neff, D., Gentaz, L., Rebiscoul, D., 2016. Effect of natural and synthetic iron corrosion products on silicate glass alteration processes. Geochimica et Cosmochimica Acta 172, 287-305.

Fleury, B., Godon, N., Ayral, A., Gin, S., 2013. SON68 glass dissolution driven by magnesium silicate precipitation. Journal of Nuclear Materials 442, 17-28.

Frugier, P., Gin, S., Minet, Y., Chave, T., Bonin, B., Godon, N., Lartigue, J.E., Jollivet, P., Ayral, A., De Windt, L., Santarini, G., 2008. SON68 nuclear glass dissolution kinetics: Current state of knowledge and basis of the new GRAAL model. Journal of Nuclear Materials 380, 8-21.

Gaucher, E.C., Tournassat, C., Pearson, F.J., Blanc, P., Crouzet, C., Lerouge, C., Altmann, S., 2009. A robust model for pore-water chemistry of clayrock. Geochimica Et Cosmochimica Acta 73, 6470-6487.

Gin, S., Guittonneau, C., Godon, N., Neff, D., Rebiscoul, D., Cabie, M., Mostefaoui, S., 2011. Nuclear Glass Durability: New Insight into Alteration Layer Properties. Journal of Physical Chemistry C 115, 18696-18706.

Gin, S., Jollivet, P., Rossa, G.B., Tribet, M., Mougnaud, S., Collin, M., Fournier, M., Cadel, E., Cabie, M., Dupuy, L., 2017. Atom-Probe Tomography, TEM and ToF-SIMS study of borosilicate glass alteration rim: A multiscale approach to investigating ratelimiting mechanisms. Geochimica Et Cosmochimica Acta 202, 57-76.

Gin, S., Mestre, J.P., 2001. SON 68 nuclear glass alteration kinetics between pH 7 and $\mathrm{pH}$ 11.5. Journal of Nuclear Materials 295, 83-96. 
Godon, N., Gin, S., Rebiscoul, D., Frugier, P., 2013. SON68 Glass Alteration

Enhanced by Magnetite. Procedia Earth and Planetary Science 7, 300-303.

Grambow, B., 1987. Nuclear Waste glass dissolution: Mechanism, model and application in: JSS-Projecy (Ed.), Report to the JSS-Project Phase IV.

Hanesch, M., 2009. Raman spectroscopy of iron oxides and (oxy)hydroxides at low laser power and possible applications in environmental magnetic studies.

Geophysical Journal International 177, 941-948.

Inagaki, Y., Ogata, A., Furuya, H., Idemitsu, K., Banba, T., Maeda, T., 1996. Effects of redox condition on waste glass corrosion in the presence of magnetite, in: Murphy, W.M., Knecht, D.A. (Eds.), Scientific Basis for Nuclear Waste Management Xix, pp. 257-264.

Jollivet, P., Angeli, F., Cailleteau, C., Devreux, F., Frugier, P., Gin, S., 2008. Investigation of gel porosity clogging during glass leaching. J. Non-Cryst. Solids 354, $4952-4958$.

Jollivet, P., Frugier, P., Parisot, G., Mestre, J.P., Brackx, E., Gin, S., Schumacher, S., 2012a. Effect of clayey groundwater on the dissolution rate of the simulated nuclear waste glass SON68. Journal of Nuclear Materials 420, 508-518.

Jollivet, P., Gin, S., Schumacher, S., 2012b. Forward dissolution rate of silicate glasses of nuclear interest in clay-equilibrated groundwater. Chem. Geol. 330-331, 207-217. 
Jordan, N., Marmier, N., Lomenech, C., Giffaut, E., Ehrhardt, J.J., 2007. Sorption of silicates on goethite, hematite, and magnetite: Experiments and modelling. Journal of Colloid and Interface Science 312, 224-229.

Mayant, C., Grambow, B., Abdelouas, A., Ribet, S., Ledercq, S., 2008. Surface site density, silicic acid retention and transport properties of compacted magnetite powder. Physics and Chemistry of the Earth 33, 991-999.

McVay, G.L., Buckwalter, C.Q., 1983. Effect of Iron on Waste-Glass Leaching. Journal of the American Ceramic Society 66, 170-174.

Mercado-Depierre, S., Angeli, F., Frizon, F., Gin, S., 2013. Antagonist effects of calcium on borosilicate glass alteration. Journal of Nuclear Materials 441, 402-410.

Michelin, A., Burger, E., Leroy, E., Foy, E., Neff, D., Benzerara, K., Dillmann, P., Gin, S., 2013a. Effect of iron metal and siderite on the durability of simulated archeological glassy material. Corrosion Science 76, 403-414.

Michelin, A., Burger, E., Rebiscoul, D., Neff, D., Bruguier, F., Drouet, E., Dillmann, P., Gin, S., 2013b. Silicate Glass Alteration Enhanced by Iron: Origin and Long-Term Implications. Environmental Science \& Technology 47, 750-756.

Michelin, A., Leroy, E., Neff, D., Dynes, J.J., Dillmann, P., Gin, S., 2015. Archeological slag from Glinet: An example of silicate glass altered in an anoxic ironrich environment. Chem. Geol. 413, 28-43. 
Neeway, J., Abdelouas, A., Grambow, B., Schumacher, S., 2011. Dissolution mechanism of the SON68 reference nuclear waste glass: New data in dynamic system in silica saturation conditions. Journal of Nuclear Materials 415, 31-37.

Neff, D., 2003. Contribution of archaeological analogs to the estimation of average corrosion rates and long term corrosion mechanisms of low carbon steel in soil. Université de Technologie de Compiègne.

Neff, D., Dillmann, P., Bellot-Gurlet, L., Beranger, G., 2005. Corrosion of iron archaeological artefacts in soil: characterisation of the corrosion system. Corrosion Science 47, 515-535.

Neill, L., Gin, S., Ducasse, T., De Echave, T., Fournier, M., Jollivet, P., Gourgiotis, A., Wall, N.A., 2017. Various effects of magnetite on international simple glass (ISG) dissolution: implications for the long-term durability of nuclear glasses. npj Materials Degradation 1, 1.

Odorowski, M., Jegou, C., De Windt, L., Broudic, V., Jouan, G., Peuget, S., Martin, C., 2017. Effect of metallic iron on the oxidative dissolution of UO2 doped with a radioactive alpha emitter in synthetic Callovian-Oxfordian groundwater. Geochimica et Cosmochimica Acta 219, 1-21.

Pèlegrin, E., Calas, G., Ildefonse, P., Jollivet, P., Galoisy, L., 2010. Structural evolution of glass surface during alteration: Application to nuclear waste glasses. J. Non-Cryst. Solids 356, 2497-2508. 
Philippini, V., Naveau, A., Catalette, H., Leclercq, S., 2006. Sorption of silicon on magnetite and other corrosion products of iron. Journal of Nuclear Materials 348, 6069.

Rébiscoul, D., Burger, E., Bruguier, F., Godon, N., Chouchan, J.L., Mestre, J.P., Frugier, P., Lartigue, J.E., Gin, S., 2013. Glass-Iron-Clay interactions in a radioactive waste geological disposal: a multiscale approach. MRS Proceedings 1518, 185-190.

Rebiscoul, D., Frugier, P., Gin, S., Ayral, A., 2005. Protective properties and dissolution ability of the gel formed during nuclear glass alteration. Journal of Nuclear Materials 342, 26-34.

Rebiscoul, D., Van der Lee, A., Rieutord, F., Né, F., Spalla, O., El-Mansouri, A., Frugier, P., Ayral, A., Gin, S., 2004. Morphological evolution of alteration layers formed during nuclear glass alteration: new evidence of a gel as a diffusive barrier. Journal of Nuclear Materials 326, 9-18.

Rolland, S., Tribet, M., Broudic, V., Jollivet, P., Jégou, C., Toulhoat, P., 2012. Effect of Groundwater on the Dissolution Rate of the Simulated Nuclear Waste Glass SON68 under Gamma Irradiation. Procedia Chemistry 7, 587-592.

Romaine, A., Sabot, R., Jeannin, M., Necib, S., Refait, P., 2013. Electrochemical synthesis and characterization of corrosion products on carbon steel under argillite layers in carbonated media at 80 degrees C. Electrochimica Acta 114, 152-158. 
Rull, F., Martinez-Frias, J., Sansano, A., Medina, J., Edwards, H.G.M., 2004.

Comparative micro-Raman study of the Nakhla and Vaca Muerta meteorites. Journal of Raman Spectroscopy 35, 497-503.

Saheb, M., Descostes, M., Neff, D., Matthiesen, H., Michelin, A., Dillmann, P., 2010. Iron corrosion in an anoxic soil: Comparison between thermodynamic modelling and ferrous archaeological artefacts characterised along with the local in situ geochemical conditions. Applied Geochemistry 25, 1937-1948.

Schlegel, M.L., Bataillon, C., Brucker, F., Blanc, C., Prêt, D., Foy, E., Chorro, M., 2014. Corrosion of metal iron in contact with anoxic clay at $90{ }^{\circ} \mathrm{C}$ : Characterization of the corrosion products after two years of interaction. Applied Geochemistry 51, 1-14.

Schlegel, M.L., Martin, C., Brucker, F., Bataillon, C., Blanc, C., Chorro, M., Jollivet, P., 2016. Alteration of nuclear glass in contact with iron and claystone at $90^{\circ} \mathrm{C}$ under anoxic conditions: Characterization of the alteration products after two years of interaction. Applied Geochemistry 70, 27-42.

Thien, B.M.J., Godon, N., Ballestero, A., Gin, S., Ayral, A., 2012. The dual effect of $\mathrm{Mg}$ on the long-term alteration rate of AVM nuclear waste glasses. Journal of Nuclear Materials 427, 297-310.

Van Iseghem, P., Aertsens, M., Gin, S., Deneele, D., Grambow, B., Strachan, D., McGrail, P., Wicks, G., 2009. GLAMOR - OR HOW WE ACHIEVED A COMMON UNDERSTANDING ON THE DECREASE OF GLASS DISSOLUTION KINETICS, in: Cozzi, A., Ohji, T. (Eds.), Environmental Issues and Waste Management 
Technologies in the Materials and Nuclear Industries Xii. Amer Ceramic Soc,

Westerville, pp. 115-126.

Vienna, J.D., Ryan, J.V., Gin, S., Inagaki, Y., 2013. Current Understanding and Remaining Challenges in Modeling Long-Term Degradation of Borosilicate Nuclear Waste Glasses. Int. J. Appl. Glass Sci. 4, 283-294.

Wray, J.L., Daniels, F., 1957. PRECIPITATION OF CALCITE AND ARAGONITE. Journal of the American Chemical Society 79, 2031-2034. 


\section{Table and figure captions}

Table 1: Theoretical SON68 glass compositions in oxide weight percent.

Table 2: Theoretical chemical composition of the Callovo-Oxfordian clayey

groundwater $\left(\mathrm{mmol} . \mathrm{L}^{-1}\right)$ and $\mathrm{pH}$ measured at $20^{\circ} \mathrm{C}$.

Table 3: $\mathrm{pH}$ values and results by ICP-AES of the solutions composition before (initial solution) and after the experiments (mg. $\left.\mathrm{L}^{-1}\right)$. GFel stands for "glass-iron interaction", Bk for the glass-Teflon blank experiment, PreCor for pre-corroded iron foil.

Table 4: Thickness of the glass alteration layer in the confined and in the diluted environment of all samples. GFel stands for "Glass-iron interaction", Bk for the blank experiment, GFel-PreCor for "Glass-pre-corroded iron foil".

Figure 1: Experimental setup: introduction of a model crack in a stainless-steel vessel with $30 \mathrm{~mL}$ of a COx groundwater solution and $10 \mathrm{~mL}$ of $\mathrm{N}_{2}$ atmosphere. Leaching for 30 and 105 days at $90^{\circ} \mathrm{C}$. PreCor Fe stands for pre-corroded iron foil.

Figure 2: SEM images on the surface of the pre-corroded iron foil and on a polished cross-section of the pre-corroded iron foil after 30 days in COx groundwater (PreCor 30 days) and the Raman spectra of the phases observed at the surface of the precorroded iron foil containing mainly $\mathrm{Ca}$ and $\mathrm{O}$ and the corroded bulk.

Figure 3: SEM observations on the model crack experiments using a pristine iron foil (GFel - 14 days) (GFel - 105 days) and a pre-corroded iron foil (GFel - PreCor- 14 days) after 14 days and 105 days of leaching. SEM images of a global observation on the model cracks, the glass alteration layer on the confined environment and the glass alteration in the diluted environment. 
Figure 4: TEM image and EDS analysis on the alteration layer of the SON68 glass in the confined environment after 14 days of leaching (GFel - 14 days). The scale bar represents $1 \mu \mathrm{m}$.

Figure 5: Increase of the thickness of the glass alteration layer in the confined (centre of the model crack) in blue and the diluted environment in orange versus time. The experimental data was obtained using different SEM images. Two data points were used for this figure and for each curve. The shape of the graph was obtained assuming a drop on glass alteration (Vienna et al., 2013). 
Table 1

\begin{tabular}{lcccccccccc}
\hline Oxides & $\mathrm{SiO}_{2}$ & $\mathrm{~B}_{2} \mathrm{O}_{3}$ & $\mathrm{Na}_{2} \mathrm{O}$ & $\mathrm{Al}_{2} \mathrm{O}_{3}$ & $\mathrm{CaO}$ & $\mathrm{ZnO}$ & $\mathrm{Li}_{2} \mathrm{O}$ & $\mathrm{Fe}_{2} \mathrm{O}_{3}$ & $\mathrm{P}_{2} \mathrm{O}_{5}$ & $\mathrm{NiO}$ \\
\hline SON68 & 45.6 & 14.06 & 9.89 & 4.93 & 4.05 & 2.51 & 1.99 & 2.92 & 0.28 & 0.74 \\
\hline \hline Oxides & $\mathrm{Cr}_{2} \mathrm{O}_{3}$ & $\mathrm{ZrO}_{2}$ & $\mathrm{Cs}_{2} \mathrm{O}$ & $\mathrm{SrO}$ & $\mathrm{Y}_{2} \mathrm{O}_{3}$ & $\mathrm{MoO}_{3}$ & $\mathrm{MnO}_{2}$ & $\mathrm{CoO}$ & $\mathrm{Ag}_{2} \mathrm{O}$ & $\mathrm{CdO}$ \\
\hline SON68 & 0.51 & 2.66 & 1.42 & 0.33 & 0.2 & 1.71 & 0.72 & 0.12 & 0.03 & 0.03 \\
\hline \hline Oxides & $\mathrm{Sb}_{2} \mathrm{O}_{3}$ & $\mathrm{SnO}_{2}$ & $\mathrm{TeO}_{2}$ & $\mathrm{BaO}$ & $\mathrm{La}_{2} \mathrm{O}_{3}$ & $\mathrm{CeO}_{2}$ & $\mathrm{Pr}_{2} \mathrm{O}_{3}$ & $\mathrm{Nd}_{2} \mathrm{O}_{3}$ & & \\
\hline SON68 & 0.01 & 0.02 & 0.23 & 0.6 & 0.9 & 0.93 & 0.44 & 2.13 & & \\
\hline
\end{tabular}


Table 2

\begin{tabular}{cccccccccc}
\hline $\mathrm{Si}$ & $\mathbf{N a}$ & $\mathbf{K}$ & $\mathbf{C a}$ & $\mathbf{M g}$ & $\mathbf{S r}$ & $\mathbf{C l}$ & $\mathbf{S O}_{4}{ }^{2-}$ & $\mathbf{H C O}_{3}{ }^{-}$ & $\mathbf{p H}^{20^{\circ} \mathrm{C}}$ \\
\hline 0.56 & 41.00 & 0.99 & 10.00 & 3.20 & 0.19 & 41.00 & 12.00 & 5.90 & 6.36
\end{tabular}


Table 3

\begin{tabular}{|c|c|c|c|c|c|c|c|c|c|}
\hline Sample & Si & B & $\mathbf{L i}$ & $\mathrm{Fe}$ & $\mathrm{Na}$ & $\mathrm{Ca}$ & Mg & Sr & $\mathrm{pH}^{20^{\circ} \mathrm{C}}$ \\
\hline $\begin{array}{c}\text { Initial } \\
\text { solution }\end{array}$ & $15.5 \pm 0.5$ & $<0.5$ & $<0.5$ & $<0.5$ & $930 \pm 28$ & $389 \pm 12$ & $77 \pm 2$ & $16.2 \pm 0.5$ & $6.3 \pm 0.1$ \\
\hline $\begin{array}{l}\text { PreCor } \\
30 \text { days }\end{array}$ & $1.73 \pm 0.2$ & $<0.5$ & $<0.5$ & $5.8 \pm 0.2$ & $971 \pm 29$ & $330 \pm 10$ & $76 \pm 2$ & $14.9 \pm 0.5$ & $6.6 \pm 0.1$ \\
\hline $\begin{array}{c}\text { GFel- } \\
\text { PreCor - } \\
14 \text { days }\end{array}$ & $9.1 \pm 0.3$ & $4.8 \pm 0.1$ & $1.8 \pm 0.1$ & $1.2 \pm 0.1$ & $1161 \pm 35$ & $400 \pm 12$ & $86 \pm 3$ & $17.7 \pm 0.5$ & $8.1 \pm 0.1$ \\
\hline $\begin{array}{c}\mathrm{Bk}-14 \\
\text { days }\end{array}$ & $24.0 \pm 0.7$ & $<0.5$ & $<0.5$ & $2.4 \pm 0.1$ & $1018 \pm 31$ & $411 \pm 12$ & $85 \pm 2$ & $17.1 \pm 0.5$ & $7.2 \pm 0.1$ \\
\hline $\begin{array}{l}\text { GFel - } \\
14 \text { days }\end{array}$ & $3.5 \pm 0.1$ & $3.3 \pm 0.1$ & $1.6 \pm 0.1$ & $25.5 \pm 0.8$ & $1087 \pm 33$ & $367 \pm 11$ & $89 \pm 3$ & $15.4 \pm 0.5$ & $7.1 \pm 0.1$ \\
\hline $\begin{array}{c}\text { GFel - } \\
105 \text { days }\end{array}$ & $2.5 \pm 0.1$ & $7.5 \pm 0.2$ & $2.5 \pm 0.1$ & $1.7 \pm 0.1$ & $1128 \pm 34$ & $373 \pm 11$ & $85 \pm 3$ & $15.2 \pm 0.5$ & $7.0 \pm 0.1$ \\
\hline
\end{tabular}


Table 4

\begin{tabular}{ccc}
\hline Sample & Confined environment & Diluted environment \\
\hline $\begin{array}{c}\text { GFel-PreCor } \\
14 \text { days }\end{array}$ & $1.3 \pm 0.4 \mu \mathrm{m}$ & $2.3 \pm 0.3 \mu \mathrm{m}$ \\
$\begin{array}{c}\text { GFel } \\
14 \text { days }\end{array}$ & $1.3 \pm 0.3 \mu \mathrm{m}$ & $3.6 \pm 0.5 \mu \mathrm{m}$ \\
\hline $\begin{array}{c}\text { GFel } \\
105 \text { days }\end{array}$ & $2.2 \pm 0.4 \mu \mathrm{m}$ & $8.0 \pm 0.7 \mu \mathrm{m}$ \\
\hline $\begin{array}{c}\text { Bk } \\
14 \text { days }\end{array}$ & $<300 \mathrm{~nm}$ & $<300 \mathrm{~nm}$ \\
\hline
\end{tabular}




\section{Figure 1}

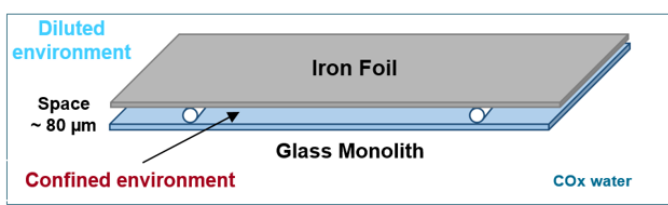

Non pre-corroded iron foil

Pre-corroded iron foil

Diluted
environment
Space
$\sim 80 \mu \mathrm{m}$

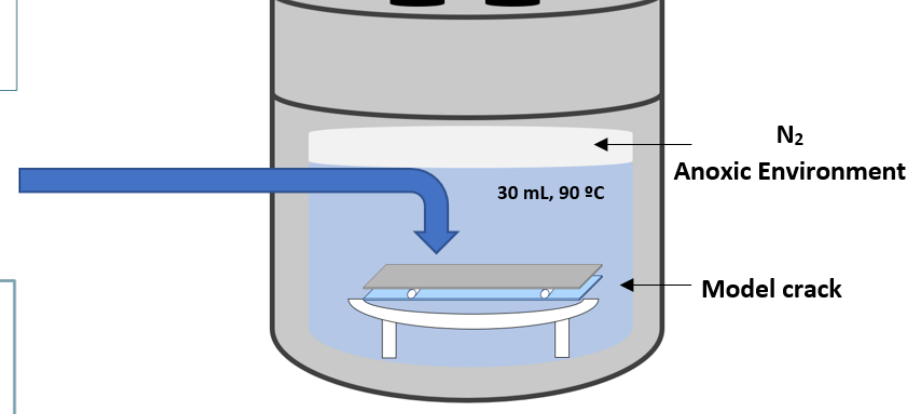


Figure 2

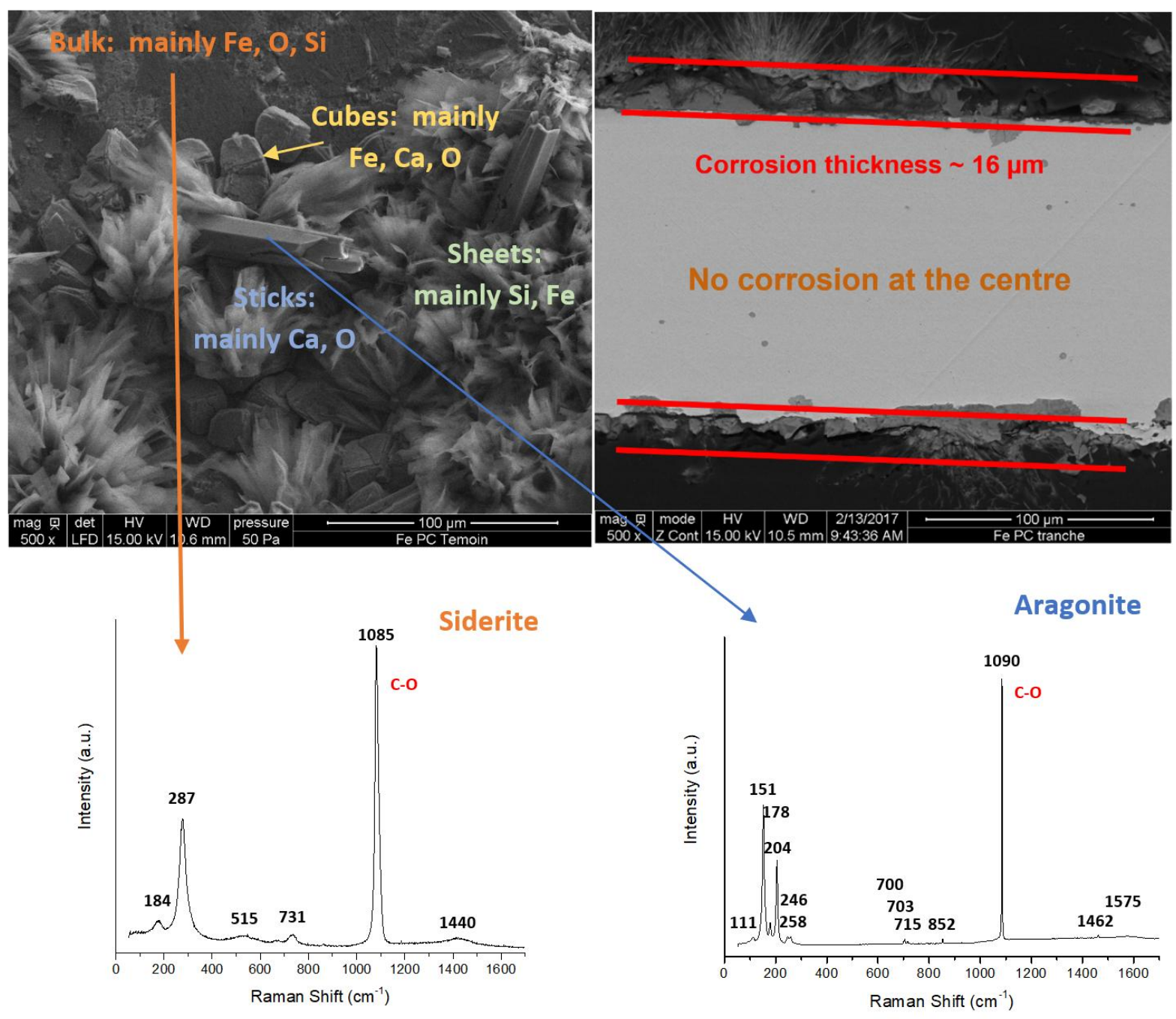


Figure 3
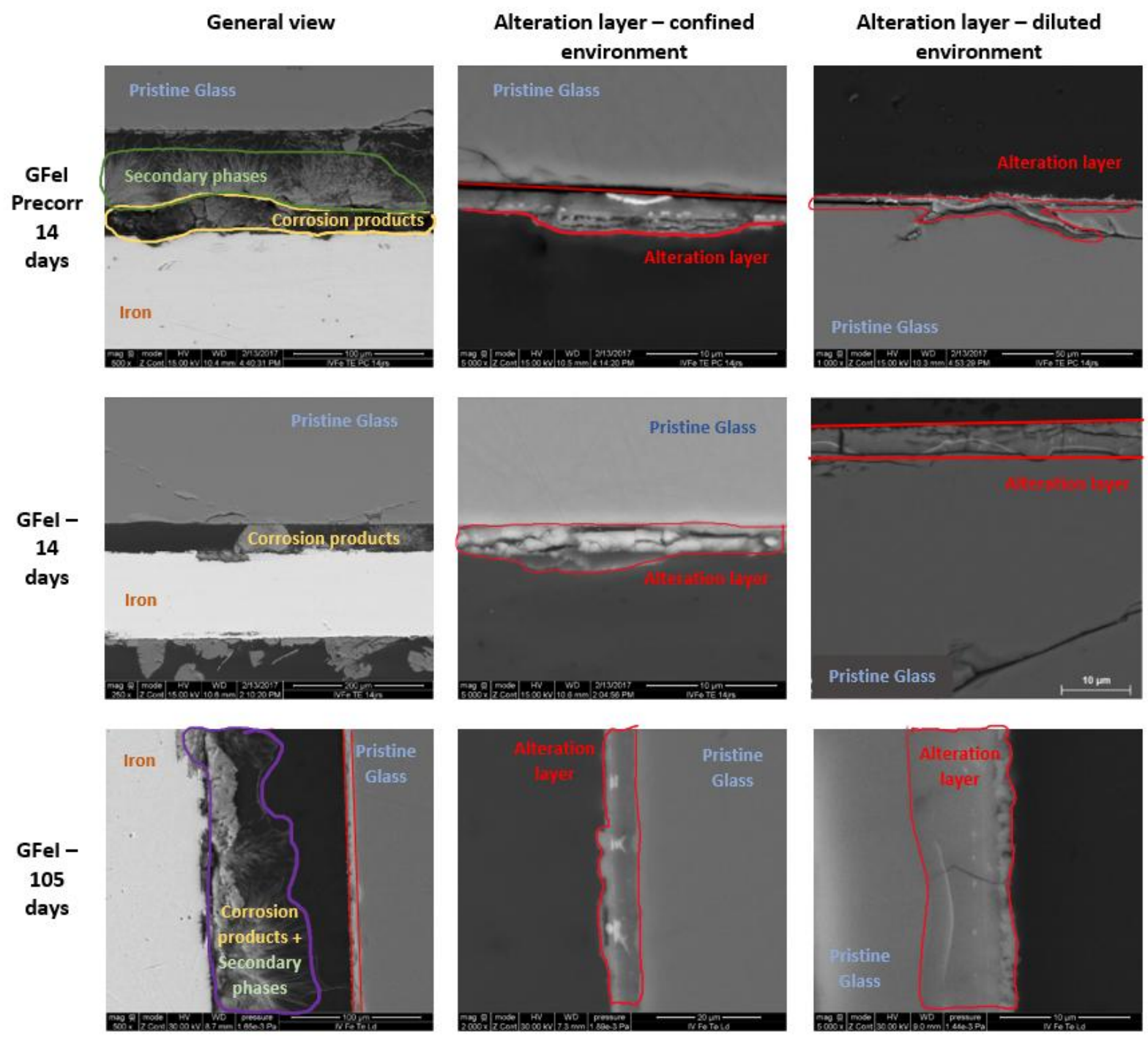
Figure 4
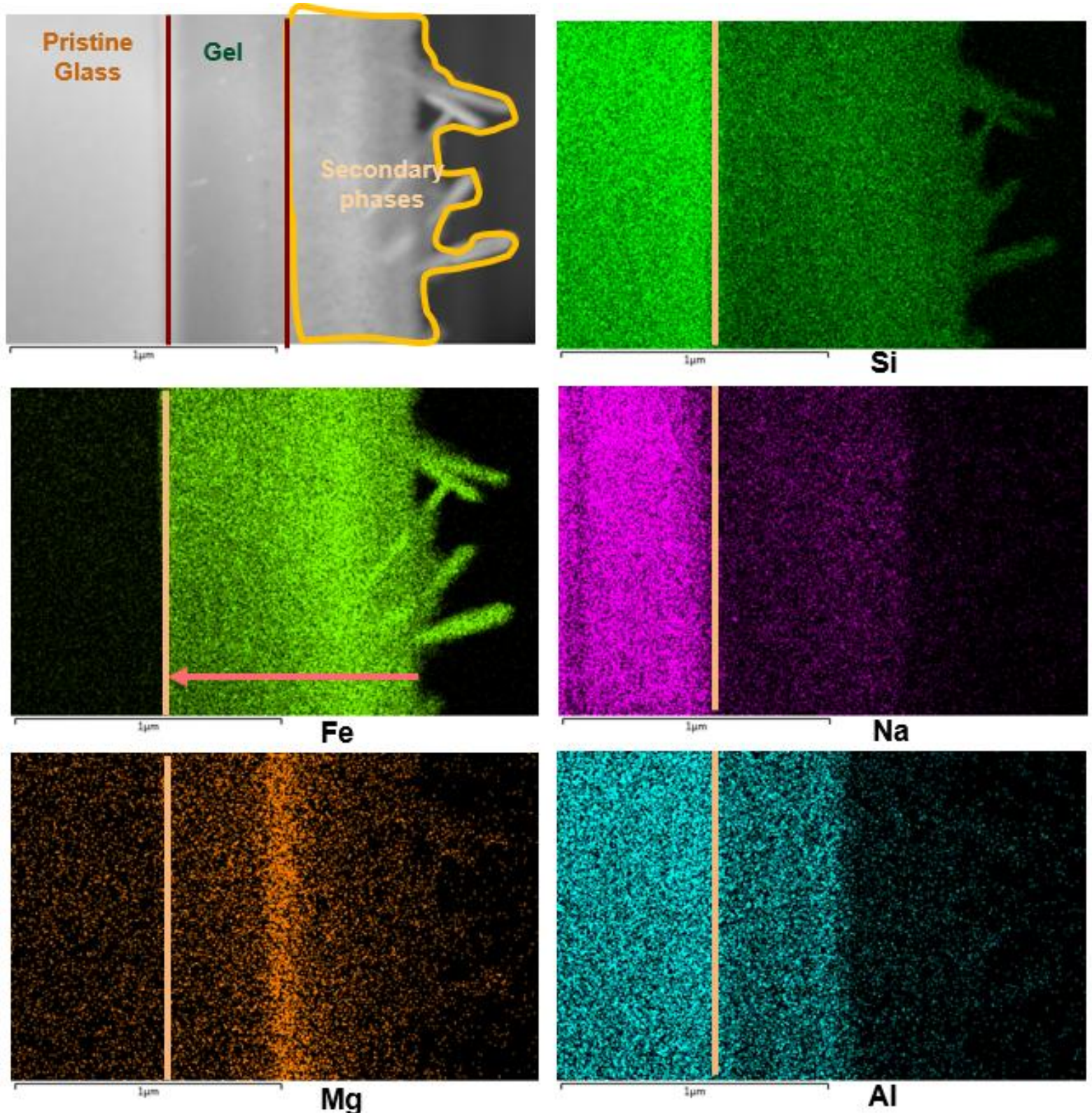
Figure 5

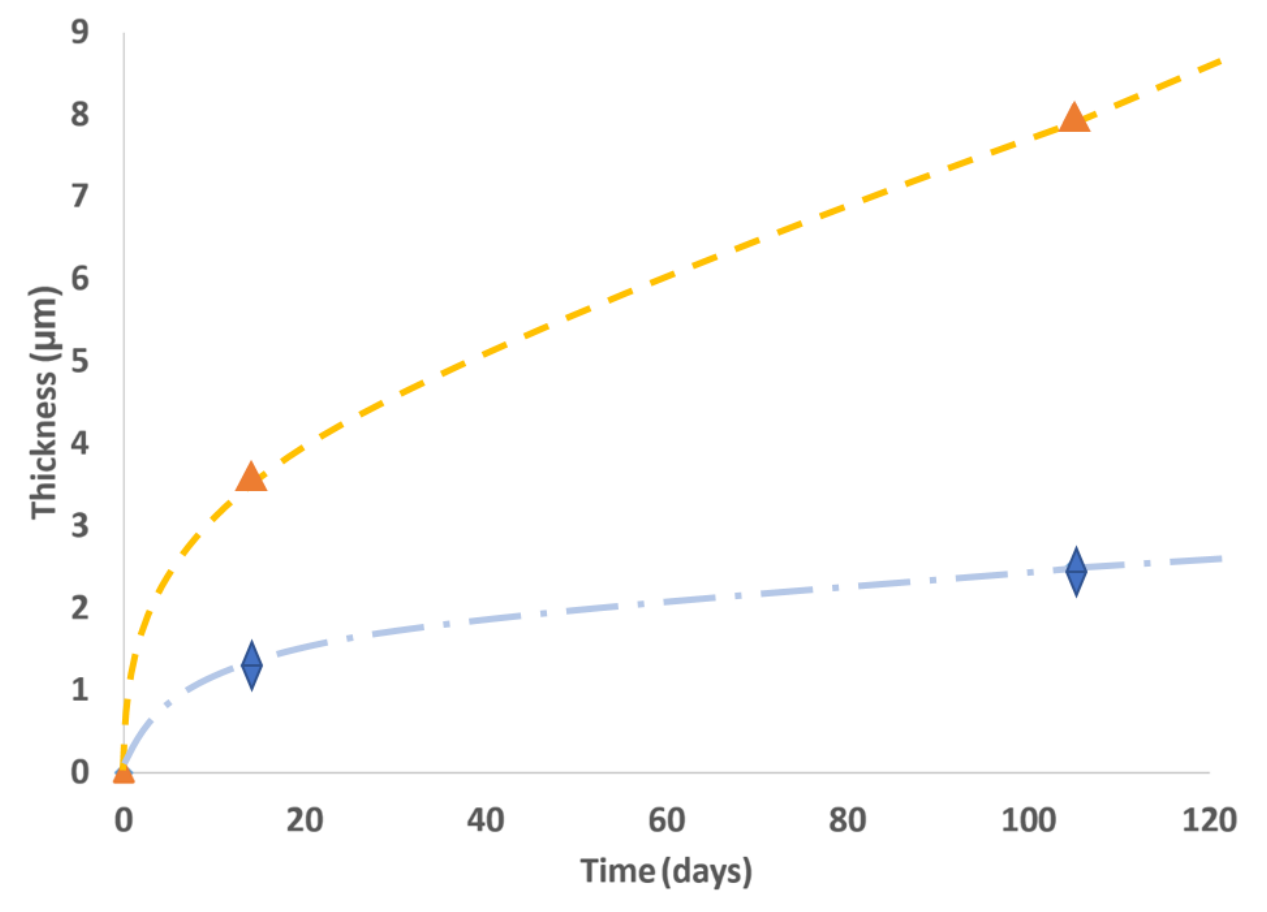

